\title{
Heterogeneity of carrot seeds depending on their position on the mother plant
}

\author{
Nikolay Panayotov \\ Agricultural University of Plovdiv \\ 12 Mendeleev, 4000 Plovdiv, Bulgaria \\ e-mail: nikpan@au-plovdiv.bg
}

\begin{abstract}
The period of vegetation and flowering of carrot usually is very long, and the flowers are formed in different parts of the mother plants. This leads to the formation of seeds with different qualities. Often heterogeneity is of a maternal type, which depends on the position of the umbels on the mother plants. The main goal of the present study was to investigate the quality differences in carrot seeds from different parts of the mother plant. The seedstalks from 'Nantski', a typical Bulgarian cultivar, were grown by the conventional method for seed production technology. In botanical maturity the seeds from the primary, secondary and tertiary umbels were extracted separately. The seed yield from umbels, dry weight of the seeds, seed size, length, width and thickness, weight per seed, 1000 seed weight, germination energy (first count), germination capacity (final count), mean germination time, uniformity of germination, fresh weight of seedlings, length of radicle, length of hypocotyls and vigour indexes were investigated. The contents of raw protein, sugar, lipids and the basic calorific values were also analysed. The germination was the highest for the seeds from primary umbels, followed by the ones from secondary umbels and lowest for those from the tertiary umbels. The difference between the highest and the lowest value was $6.30 \%$. These results suggest that it is better to harvest the carrot seeds depending on their position on the plant and divide them into separate lots with different qualities.
\end{abstract}

Key words: calorific values, Daucus carota L., germination, seed, seedling, vigour, yield

\section{INTRODUCTION}

Seed quality depends on the stage of growth and on the status of plant. The period of vegetation and flowering for carrot usually is very long, and the flowers are set at different mother plant parts and the seeds are formed in the plants at different development stages. This leads to the formation of seeds with various qualities. Often the heterogeneity is of a maternal type, which is determined by the position of the seeds on the mother plants (Panayotov 2005).

Muniz (1999) reported that seeds from king umbels had higher quality than those from secondary ones. Gray (1979) emphasized the significance of seed position on the seedstalk upon the seed quality. Szafirowska (1994) proved that the germination capacity and the weight of 1,000 seeds from primary umbels were higher than those of the seeds from other umbels. The carrot seeds from primary and secondary umbels had higher percentages of germination capacity and developed larger seeds than those from the high order umbels (Corbineau et al. 1995). Other authors (Satyaveer et al. 1994, Shantha et al. 1999) also established the same information. However, some researchers substantiated the opposite affirmation, that they had found the best quality in carrot seeds from secondary umbels (Elballa and Cantliffe 1997).

The main aim of the present study was to investigate the differences in quality of the carrot seeds, depending on their position on the mother plant.

\section{MATERIAL AND METHODS}

The experiments were carried out in the Experimental Field of the Department of Horticulture and Central Laboratory at the Agricultural University of Plovdiv, Bulgaria, during 2005-2008, with the typical Bulgarian 
carrot cultivar 'Nantski'. The plants were grown using the conventional technology for carrot seed production under Bulgarian conditions, sowing in the middle of June, harvesting the carrot roots (stecklings) in November, steckling storage during the winter in soil-covered pits and transplanting in the middle of March by a scheme of $80 \times 30 \mathrm{~cm}$.

The seeds from 20 plants were extracted in full botanical maturity separately from primary, secondary and tertiary umbels. The seed yield is presented as a percentage of seeds formed in different umbels to the total seed productivity of one carrot seedstalk. The airdry weight of seeds (dried in the open air) was determined by the method described by Georgiev et al. (1980) in three replications. The average sizes of seeds - length, width, thickness and weight per seed - were determined for 15 seeds. The germination energy (first count) and germination capacity (final count, germination) in four replications, each of them by 100 seeds taken at random (ISTA 2003) and the weight of 1000 seeds in four replications (ISTA 2003), were established. The fresh weight of seedling per seed was measured for all seedlings developed from the above-mentioned four replications at the moment of determining the germination. The length of the radicle and hypocotyl, measured in 10 seedlings from each of the above-mentioned four replications were investigated at the moment of determining the germination. The mean germination time (MGT) in four replications, each of them by 100 seeds taken at random, was calculated using the equation:

$$
\text { MGT }=\frac{\sum(\mathrm{G} \times \mathrm{T})}{\mathrm{F}}
$$

where $\mathrm{T}=$ the day on which the germination rate was reported, $G=$ the number of seeds germinated on the counting day, and $\mathrm{F}=$ the final number of seeds that germinated (Battle and Whittington 1969).

The uniformity of germination in four replications, each of them by 100 seeds taken at random, was investigated by the equation described by Strona (1966). The content of dry weight of the seeds (by consecutive oven-drying and weighing until reaching a constant weight in two consecutive measurements), the total sugar as glucose (by Hagedorn-Yensen), raw protein (by Kjeldahl method) and lipid content (using the Sokslet apparatus and extraction with diethyl ether) in seeds in three replications were also established, for these four parameters, implementing the methods described by Stambolova et al. (1978). The basic calorific value per seed in three replications was calculated by the content of sugar, raw protein and lipids and their calories per seed based on the dry weight and weight per seed by the method described in detail by Panayotov and Stoeva (2009).

The seed vigour in these experiments was described through their parameters, such as fresh weight of seedling per seed, weight of seed as well as weight of 1000 seeds, and final count of germination. The vigour index of one seed in four replications, each by 100 seeds, was determined as a ratio between fresh weight of seedling to weight per seed. The vigour index of the sample (four replications, each by 100 seeds) was calculated as 1000 seed weight multiplied by the final percentage of germination/100 (Elliott 2001). The statistical analyses were made by ANOVA. Data of the study were subjected to analysis of variance, and least significant differences between means were calculated by the Fisher test at $\mathrm{p}=0.05$. A linear correlation was made by Fowel and Cohen (1992). The presented data are mean values from the three years of the investigation periods, because the trends were similar.

\section{RESULTS AND DISCUSSION}

A correlation between size of carrot seeds and their germination is one of the main reasons for differences in their quality (Anouar et al. 2001). The highest length for the carrot seeds (Tab. 1) was established for those of secondary umbels: $2.62 \mathrm{~mm}$. For primary and tertiary umbels, the differences were not found. The differences between secondary and primary umbels $(0.3 \mathrm{~mm})$ and between secondary and tertiary umbels $(0.27 \mathrm{~mm})$ were within statistical significance. The width was the highest for the seeds from primary umbels and the thickness for the tertiary $-1.72 \mathrm{~mm}$ and $0.95 \mathrm{~mm}$, respectively. The differences for the first characteristic were statistically

Table 1. Plant productivity and morphological traits of carrot seed

\begin{tabular}{|c|c|c|c|c|c|c|}
\hline Variants & $\begin{array}{c}\text { Yield } \\
\text { per plant } \\
(\%)\end{array}$ & $\begin{array}{c}\text { Length } \\
\text { of seed } \\
(\mathrm{mm})\end{array}$ & $\begin{array}{c}\text { Width } \\
\text { of seed } \\
(\mathrm{mm})\end{array}$ & $\begin{array}{c}\text { Thickness } \\
\text { of seed } \\
(\mathrm{mm})\end{array}$ & $\begin{array}{c}\text { Weight } \\
\text { of seed } \\
(\mathrm{mg})\end{array}$ & $\begin{array}{c}1000 \text { seed } \\
\text { weight } \\
(\mathrm{g})\end{array}$ \\
\hline Primary umbels & 27.16 & 2.32 & 1.72 & 0.75 & 2.34 & 1.91 \\
\hline Secondary umbels & 42.85 & 2.62 & 1.21 & 0.75 & 2.21 & 1.87 \\
\hline Tertiary umbels & 30.97 & 2.35 & 1.30 & 0.95 & 2.15 & 1.74 \\
\hline $\mathrm{LSD}_{0.05}$ & 10.16 & 0.21 & 0.32 & 0.07 & 0.43 & 0.23 \\
\hline
\end{tabular}


significant, while for thickness that referred only for the difference between the obtained results between the primary and tertiary umbels $(-0.20 \mathrm{~mm})$. The seeds from the primary umbels were characterized by their higher weight $(2.34 \mathrm{mg}), 0.13 \mathrm{mg}$ more than those from the secondary umbels and $0.19 \mathrm{mg}$ higher than from the tertiary umbels. The 1000 seed weight followed the same trend and was the biggest for seeds developed in the primary umbels $-1.91 \mathrm{~g}$. It could be due to the fact that the primary umbel flowering started the earliest and seeds developed for a longer period. The values of this parameter were the lowest in the seeds from the tertiary umbels. Mathematical significance for both indexes was not established.

The separate parts of the seedstalk participated differently in the formation of the seed productivity. The highest seed yield was obtained from secondary umbels $-42.8 \%$ of the total yield, followed by the tertiary, with $11.8 \%$ less, while the lowest was from the primary umbels. It could be suggested that these results are related to the fact that the king umbel is a single inflorescence, on the one hand, and, on the other hand, to the small size of the tertiary umbels and the small weight of their seeds. The differences were statistically significant, except for the difference between the first and tertiary umbels.

The most important seed characteristic is their sowing quality. The data are shown in Table 2. For germination energy some differences were established. The highest values were determined for seeds from primary umbels (66.7\%), while for secondary and for tertiary umbels they were lower by $5.0 \%$ and $8.0 \%$, respectively. The results were statistically significant. A similar tendency was observed regarding germination. The highest percentage of germinated seeds was also registered for primary umbels $-78.0 \%$. The germination of seeds from secondary umbels $(75.0 \%)$ was close to that result. The difference of germination capacity between the primary and tertiary umbels $(6.3 \%)$ was statistically significant. The difference between the highest and the lowest germination capacity was $6.3 \%$ and it referred to the seeds from the tertiary umbels. This indicates that the seeds, which were formed in the early stage of vegetation and flowering of the carrot, showed better germination. A similar conclusion, that the primary umbels developed seeds with better quality, was also made by Muhammad and Anjum (2001). Matthews and Khajeh Hosseini (2006) emphasised that mean germination time is a possible factor for better assessment of seed status. In these experiments the shortest mean germination time was found for seeds from the secondary umbels, followed by those of the primary ones. The difference in this parameter between seeds from the secondary and those from the tertiary umbels was approximately one day (0.86). The best uniformity of germination was also noted for seeds from the secondary umbels (14.4\%). The values for the other umbels were similar. The results for mean germination time and uniformity of germination were not proved.

Along with germination, seed vigour has great significance for establishing their status. Copeland and McDonald (2001) emphasized that through evaluation of seed vigour, information could be collected for the abilities of the seeds not only to germinate, but also to develop normal seedlings. One of the parameters describing vigour is the fresh weight of seedlings (Tab. 3). In this parameter, the differences were statistically significant. The seeds from the primary umbels developed seedlings with the highest weight $(20.6 \mathrm{mg})$. The weight was lower for seeds from the secondary umbels $(19.2 \mathrm{mg})$ and the lowest for

Table 2. Sowing quality of carrot seeds

\begin{tabular}{|c|c|c|c|c|}
\hline Variants & $\begin{array}{c}\text { Germination } \\
\text { energy } \\
(\%) \\
\end{array}$ & $\begin{array}{c}\text { Germination } \\
\text { capacity } \\
(\%)\end{array}$ & $\begin{array}{c}\text { Mean } \\
\text { germination time } \\
\text { (days) }\end{array}$ & $\begin{array}{c}\text { Uniformity } \\
\text { of germination } \\
(\%) \\
\end{array}$ \\
\hline Primary umbels & 66.7 & 78.0 & 5.37 & 13.2 \\
\hline Secondary umbels & 61.7 & 75.0 & 4.82 & 14.4 \\
\hline Tertiary umbels & 58.7 & 71.7 & 5.68 & 13.0 \\
\hline $\mathrm{LSD}_{0.05}$ & 4.88 & 3.56 & 1.40 & 4.98 \\
\hline
\end{tabular}

Table 3. Vigour characteristics of carrot seeds

\begin{tabular}{|c|c|c|c|c|c|}
\hline Variants & $\begin{array}{c}\text { Fresh weight } \\
\text { of seedling } \\
(\mathrm{mg})\end{array}$ & $\begin{array}{l}\text { Length } \\
\text { of radicle } \\
(\mathrm{cm})\end{array}$ & $\begin{array}{c}\text { Length } \\
\text { of hypocotyl } \\
(\mathrm{cm}) \\
\end{array}$ & \multicolumn{2}{|c|}{ Vigour index of: } \\
\hline Primary umbels & 20.60 & 3.34 & 3.89 & 9.32 & 1.46 \\
\hline Tertiary umbels & 17.20 & 2.83 & 3.20 & 8.00 & 1.31 \\
\hline $\mathrm{LSD}_{0.05}$ & 1.47 & 0.70 & 0.52 & 2.82 & 0.09 \\
\hline
\end{tabular}


Table 4. Chemical components and basic calorific values of carrot seeds

\begin{tabular}{|c|c|c|c|c|c|c|}
\hline Variants & $\begin{array}{c}\text { Air-dry weight } \\
(\%)\end{array}$ & $\begin{array}{c}\text { Dry } \\
\text { weight } \\
(\%) \\
\end{array}$ & $\begin{array}{c}\text { Raw } \\
\text { protein } \\
(\%)\end{array}$ & $\begin{array}{c}\text { Sugar } \\
\text { as a glucose } \\
(\%)\end{array}$ & $\begin{array}{l}\text { Lipids } \\
(\%)\end{array}$ & $\begin{array}{c}\text { Basic } \\
\text { calorific value } \\
(\mathrm{J})\end{array}$ \\
\hline Primary umbels & 84.41 & 91.26 & 17.97 & 10.62 & 17.98 & 26.32 \\
\hline Secondary umbels & 82.56 & 90.31 & 13.87 & 10.87 & 16.96 & 24.77 \\
\hline Tertiary umbels & 81.54 & 90.86 & 16.58 & 5.67 & 11.26 & 18.12 \\
\hline r* with germination & & & & & & 0.67 \\
\hline
\end{tabular}

the tertiary ones. Other morphological characteristics of seedlings are length of radicle and hypocotyl. These were highest for secondary umbels seeds, $3.71 \mathrm{~cm}$ and $4.03 \mathrm{~cm}$, respectively. The values for the primary umbels were very close. Greater differences were established in seeds from the tertiary umbels, which were $0.88 \mathrm{~cm}$ and $0.83 \mathrm{~cm}$ smaller than the secondary umbels. The differences between the data about the secondary and tertiary umbels for the above parameters of seedlings, as well as differences in hypocotyl length between the first and secondary umbels, were statistically significant.

The vigour test is a more sensitive index of seed quality than the standard germination test, and this parameter described better seed status (Delouche and Baskin 1973, Schmidt 2000). In these experiments the vigour index per seed varied from 8.00 for tertiary umbels to 9.32 for seeds from primary umbels, but the differences were not within statistical significance. Vigour index per sample was also the highest for primary umbels seeds (1.46) while for the other umbels it was 1.42 and 1.31 , respectively. The results were statistically significant except for the difference between the primary and secondary umbels. The vigour is a summarizing parameter and the obtained results for it once again confirmed that the seeds from the primary umbels had very good sowing quality, followed by those from the secondary umbels. Therefore, in order to offer the highest quality seeds, after harvesting seedstalk in the common way, by swathing and through cutting the umbels, it is better to extract the carrot seeds depending on their position on the plant and divide them in separate lots with different qualities. Pereira et al. (2008) also expressed the same conclusion that separate harvesting is more appropriate.

The seed dry weight is one of the most significant characteristics for the description of the seed status (Copeland and Mc Donald 2001). The data are shown in Table 4 . The air-dry weight was at the maximum content in seeds formed in the flowers of primary umbels: $84.4 \%$. The values for the other seeds were close to each other and lower than the ones in primary umbel seeds, and the differences with the primary umbels were statistically significant. The dry weight changed in short limits. It must be pointed out that it was also highest in seeds from primary umbels $(91.2 \%)$, but the differences between variants were not very big and statistical significance was established only for the differences between the results for primary and secondary umbels $(0.9 \%)$. The content of raw protein was the highest in seeds from primary umbels, and decreased for umbels from the other orders. In that sense the highest values were established in the primary umbels seeds $-17.9 \%$, or $4.1 \%$ higher than in seeds from the secondary, i.e. the difference was of statistical significance and $1.3 \%$ higher than the tertiary ones. Ones of the main energetic components are the lipids. Their content was the highest in seeds developed in the primary umbels: $17.9 \%$. This value exceeded the content in seeds from the secondary and from tertiary umbels by $1.0 \%$ and $6.7 \%$, respectively. A high content of sugar was found in seeds from the secondary umbels $(10.8 \%)$, while in primary umbels it was very close, but for tertiary ones the values were half. The differences in the contents of both chemical components (sugar and lipids) between the obtained data for the primary and tertiary and for the secondary and tertiary umbels were statistically significant. According to the abovementioned contents of the main chemical components in the seeds, differences were also established for the basic calorific value. This parameter gives additional information about the available energy in the seed, which enables the seeds for emergence and for development of the seedling. The highest basic calorific value was calculated for the seeds, originating from the primary umbels: $26.32 \mathrm{~J}$. The value of later formed seeds, from secondary umbels, was $1.55 \mathrm{~J}$ less. Still lower was the value of this index in the last developed seed, from the tertiary umbels: $18.12 \mathrm{~J}$. The results were statistically significant. A high positive correlation coefficient was calculated between germination and basic calorific values: $r=0.67$. This is a good proof for the relationship between the germination processes and supplying the seeds with nutrient elements, and also indicates that the basic calorific values can be used as a summary 
characteristic for the better description and understanding of germination.

\section{CONCLUSIONS}

1. The highest weight of one seed and of 1000 seeds was documented for the seeds from the primary and secondary umbels. Secondary umbels took the biggest share in the formation of seed yield per carrot plant.

2. The highest germination capacity was found for seeds from the primary umbels. The difference between this value and lowest percentage of germination was approximately $6.0 \%$. Better mean germination time and uniformity of germination was found in the seeds from the secondary umbels, than for seeds from the other umbels.

3. Morphological characteristics of seedlings had the highest values in seeds from the primary and from the secondary umbels seeds. The vigour index was highest for seeds from the primary umbels.

4. The maximum values of air-dry weight and dry weight and contents of raw protein and lipids were documented in the seeds from the primary umbels. They were also characterised by the highest basic calorific value, and this parameter gave an opportunity for a better description of the ability of the seeds for germination.

5. The carrot seeds with best sowing quality were those that were developed from the flowers of the primary umbels. These results suggest that it is better to extract the carrot seeds separately, depending on their position on the mother plant, and divide them into individual lots with different qualities.

\section{REFERENCES}

Anouar F., Mannino M.R., Casal M.L., Fougereux J.A., Demilly D., 2001. Carrot seeds grading using a vision system. Seed Sci. Technol. 29(1): 215-225.

Battle J.P., Whittington W.J., 1969. The influence of genetic and environmental factors on the germination of sugar beet seed. J. Agric. Sci. 73: 329-335.

Copeland L., Mc Donald M.B., 2001. Longevity and deterioration. In: Principles of seed science and technology. L. Copeland (ed.). Chapman \& Hall Ltd., London: 181-220.

Corbineau F., Picard M.A., Bonnet A., Come D., 1995. Effects of production factors on germination responses of carrot seeds to temperature and oxygen. Seed Sci. Res. 3: 129-135.

Delouche J.C., Baskin C.C., 1973. Accelerated aging techniques for predicting the relative storability of seed lots. Seed Sci. Technol. 1: 427-452.
Elballa M.M.A., Cantliffe D.J., 1997. Modification of seedstalk development and its effects on seed yield and seed quality in carrot (Daucus carota L.). J. Veg. Crop Prod. 2: 29-41.

Elliott B., 2001. Effect of seed quality on the performance of Argentine varieties in the 2001 regional test. Scientific Report of Part 4 of CARP Project \# 2003-02-01-19 of Saskatoon Research Centre, Agriculture and Agri-Food, Canada.

Fowel J., Cohen L., 1992. Practicle statistics for field biology. John Wiley \& Sons, New York, 223.

Georgiev N.G., Kovachev N.G., Tconeva P.N., Gemishev C.M., Andreev G.K., Ivanova J.A., 1980. The guidance for practical work of plant physiology. Nauka i Izkustvo, Sofia, Bulgaria: 235.

GrAY D., 1979. The germination response to temperature of carrot seeds from different umbels and time of harvest of the seed crop. Seed Sci. Technol. 7: 169-178.

ISTA, 2003. International Rules for Seed Testing. International Seed Testing Association. Bassersdorf, Switzerland.

Matthews S., Khajeh-Hosseini M., 2006. Mean germination time as an indicator of emergence performance in soil of seed lots of maize (Zea mays). Seed Sci. Technol. 34: 339-347.

Muhammad A., Anjum M.A., 2001. Effect of root size, plant spacing and umbel order on the quality of Asiatic carrot (Daucus carota L.). Indian J. Agric. Biology 3: 239-242.

Muniz M.F.B., 1999. Carrot seeds quality produced from primary and secondary umbels from Rio Grande do Sul State. Revista Brasiliera de Sementes, 21: 255-259.

Panayotov N., 2005. Technological management and factors influencing seed quality of vegetable crops. In: Vegetables: Growing Environment and Mineral Nutrition. D. Ramdane (ed.). WFL Publisher, Helsinki, Finland: 138-165.

Panayotov N., Stoeva N., 2009. Influence of the maturity on the sowing quality and vigour of the carrot seeds. Scientific Work of the Agricultural University, Plovdiv, LXV: 93-98.

Pereira R.S., Nascimento W.M., Vieira J.V., 2008. Carrot seed germination and vigor in response to temperature and umbel orders. Sci. Agric. 65: 145-150.

Satyaveer S., Nehra B.K., Malik Y.S., Singh S., 1994. Carrot seed yield and quality as influenced by different order umbels under varying nitrogen, plant density and geometry. Crop Res. Hisar 3: 543-548.

Shantha N., Pandita V.K., Sharma D., Nagarajan S., 1999. Effect of sowing time and umbel order on emergence characteristics of Asiatic carrot Daucus carota L. Seed Res. 2: 125-130.

Schmidt L., 2000. Guide to Handling of Tropical and Subtropical Forest Seed. Danida Forest Seed Centre, Denmark: 178.

Stambolova M., Chopaneva T., Argirova T., 1978. The guidance for practical work by biochemistry. Zemizdat, Sofia, Bulgaria: 213.

Strona I.G., 1966. Obshtee semenovedenie polevnih kultur. Kolos, Moskow: 235. 
SzAFIRIOWSKA A.I., 1994. The correlation between mother plant architecture, seed quality and field emergence of carrot. Acta Hort. 354: 93-97.

\section{HETEROGENICZNOŚĆ NASION MARCHWI W ZALEŻNOŚCI OD ICH POŁOŻENIA NA ROŚLINIE MACIERZYSTEJ}

Streszczenie: Okres kwitnienia marchwi jest zwykle długi, a baldachy formują się stopniowo na rozgałęzionym pędzie kwiatostanowym, co prowadzi to do uzyskania nasion o zróżnicowanej jakości. Heterogeniczność jest typu matecznego i zależy od pozycji baldachu na roślinie macierzystej. Celem prezentowanych badań była ocena różnic $\mathrm{w}$ jakości nasion marchwi pozyskanych z baldachów pochodzących $\mathrm{z}$ różnych części pędu kwiatostanowego. Pędy nasienne typowej bułgarskiej odmiany 'Nantski' pozyskano z plantacji nasiennej, na której stosowano konwencjonalną technologię uprawy.
Dojrzałe nasiona zebrano oddzielnie $\mathrm{z}$ baldachów pierwszego, drugiego i trzeciego rzędu. Określono plon nasion z baldachu, suchą masę nasion, długość, szerokość i średnicę nasiona, masę jednego nasienia, masę tysiąca nasion, wigor, energię i zdolność kiełkowania, średni czas kiełkowania, równoczesność kiełkowania, świeżą masę siewek oraz długość korzonka zarodkowego i hypokotylu. Określono również zawartość, białka, cukrów i lipidów oraz podstawową wartość kaloryczną nasion. Parametry kiełkowania były największe dla nasion pochodzących $\mathrm{z}$ baldachów pierwszego rzędu, następnie drugiego rzędu, a najmniejsze - trzeciego rzędu. Różnica pomiędzy największą i najmniejszą wartością wyniosła $6,30 \%$. Uzyskane wyniki pozwoliły na stwierdzenie, że najlepiej pozyskiwać nasiona oddzielnie z baldachów poszczególnych rzędów i dzielić je na partie o zróżnicowanej jakości.

Received June 4, 2009; accepted July 17, 2010 